\title{
Efektivitas Penggunaan Input Dalam Usaha Tani Bawang Merah Di Kecamatan Baraka Kabupaten Enrekang
}

\author{
Abdul Wahab \\ Universitas Islam Negeri Alauddin Makassar \\ abdulwahab@uin-alauddin.ac.id \\ Bahrul Ulum Rusydi \\ Universitas Islam Negeri Alauddin Makassar \\ bahrul.rusydi@uin-alauddin.ac.id \\ Nirwana \\ Universitas Islam Negeri Alauddin Makassar
}

\begin{abstract}
Abstrak
Pola kerja petani bawang merah di Kecamatan Baraka Kabupaten Enrekang masih menganut prinsip produksi model lama, dimana untuk menambah hasil panen seringkali dibarengi dengan penambahan input. Padahal dalam dimensi teori produksi Cobb-Douglas penambahan input belum tentu sejalan dengan peningkatan hasil produksi. Oleh karena itu, penelitian ini bertujuan untuk melihat efektivitas penggunaan input dalam usaha tani bawang merah yang ada di Kecamatan Baraka. Variabel input yang digunakan dalam penelitian ini meliputi luas lahan, modal, tenaga kerja, dan teknologi yang dihoptesisikan berkorelasi dengan hasil produksi bawang merah. Metode analisis yang digunakan adalah regresi linear berganda dengan mengadopsi teori produksi Cobb-Douglas. Hasil analisis terhadap variabel penelitian ditemukan bahwa penggunaan input pada usaha tani Bawang Merah berada dalam kondisi decreasing return to scale.
\end{abstract}

Kata Kunci: Pertanian, Bawang Merah, Cobb-Douglas

\section{The Effectiveness Of Using Inputs In Onion Farming Business In Baraka Sub-District, Enrekang District}

\section{Abstract}

The working pattern of shallot farmers in Enrekang Regency still adheres to the old model of production principles, were to increase production is accompanied by adding the inputs. In fact, in the dimension of the Cobb-Douglas production theory, the addition of inputs is not always necessary in line with the increase of production output. Therefore, this study aims to see the effectiveness of inputs in shallots farming in Enrekang Regency. The input variables used in this study include the area of land, capital, labor, and technology that are optimized and correlated with the production of shallots. The analytical method used is multiple linear regression by adopting the Cobb-Douglas production theory. The results of the analysis found that the use of inputs is reaching the condition of decreasing return to scale in shallots farming.

Keywords: Agricultre, Shallot, Cobb-Douglas, Enrekang

\section{PENDAHULUAN}

Bawang merah merupakan salah satu komoditas sayuran yang memiliki nilai ekonomis tinggi ditinjau dari pemenuhan konsumsi nasional dan potensinya sebagai penghasil devisa bagi negara (Sinaga \& Hastuti, 2019). Bagaimana tidak, hampir semua jenis masakan nusantara menggunakan bawang merah sebagai salah satu bahan ramuannya. Iklim tropis hangat dan tanah subur menjadikan Indonesia sebagai salah satu negara dengan penghasil bawang merah terbesar di dunia (Djauhari \& Malian, 2016).

Indonesia memiliki beberapa sentra pertanian bawang merah. Beberapa di antaranya adalah Bima di Nusa Tenggara Barat, Brebes di Jawa Tengah, dan Enrekang di Sulawesi Selatan (Aldila et al., 2017). 
Tabel 1. Produksi Bawang Merah Beberapa Setra di Indonesia

\begin{tabular}{cccc}
\hline Provinsi & $\mathbf{2 0 1 6}$ & $\mathbf{2 0 1 7}$ & $\mathbf{2 0 1 8}$ \\
\hline Sul-Sel & 96.256 & 129.181 & 92.392 \\
\hline Jateng & 546.685 & 476.337 & 445.586 \\
\hline Jatim & 304.521 & 306.316 & 367.032 \\
\hline NTB & 211.804 & 195.458 & 212.885 \\
\hline
\end{tabular}

Sumber: Kementan RI, 2019

Pada tahun 2018, Sulawesi Selatan mampu memproduksi 92.392 ton bawang merah, atau 6,14 persen dari total produksi nasional. Dari total produksi Sulawesi Selatan tersebut sebanyak 73.581 ton atau 79,64 persen merupakan sumbangsih dari Enrekang (BPS, 2019). Salah satu kecamatan dengan produksi bawang merah terbanyak adalah Baraka.

Bagi sebagian besar petani yang ada di Enrekang, pilihan untuk membudidayakan bawang merah disebabkan karena beberapa alasan. Pertama, tingginya tingkat permintaan bawang merah. Kedua, harga jual yang cukup tinggi. Ketiga, daya tahan produk yang lebih baik dibandingkan dengan produk sayuran lainnya (Muhammad Idrus, 2013).Hal yang sama juga berlaku bagi petani bawang merah di Kecamatan Baraka yang menjadi obyek riset dalam penelitian ini.

Dalam teori ekonomi, setiap unit usaha yang memerlukan input yang dikelola dalam proses produksi untuk menghasilkan output. (Shephard, 2015). Lebih lanjut, teori produksi Cobb Douglas menyebutkan bahwa setidaknya terdapat 3 input utama dalam proses produksi yaitu modal (capital), tenaga kerja (labor), dan teknologi (technology) (Cobb \& Douglas, 1928).

Teori Cobb-Douglas adalah salah satu teori yang menjadi rujukan utama dalam analisis proses produksi. Inti dati teori ini pada prinsipnya adalah memberikan gambaran mengenai efektivitas penggunaan input dan dampaknya terhadap output produksi yang dihasilkan. Terdapat 3 skenario dari hubungan tersebut, yaitu decreasing return to scale (DRS), constant return to scale (CRS), dan increasing return to scale (IRS) (McAuliffe, 2015).

Kondisi decreasing return to scale merupakan suatu kondisi dimana proporsi penambahan faktor input melebihi proporsi pertambahan produksi. Kondisi constant return to scale berarti bahwa penambahan faktor input akan proporsional dengan penambahan output produksi. Sedangkan increasing return to scale adalah kondisi dimana proporsi dari penambahan faktor input akan menghasilkan pertambahan produksi yang lebih besar (Soekartawi, 2002). Dari ketiga skenario tersebut yang paling ingin dicapai dalam proses produksi adalah kondisi increasing return to scale. Sebaliknya yang paling dihindari adalah kondisi decreasing return to scale.

Dalam suatu proses produksi, utamanya produksi pertanian, perluasan skala produksi (production scale) pada hakikatnya merupakan suatu upaya maksimalisasi produksi dalam jangka panjang. Secara teknis, dengan perluasan skala usaha rata-rata komponen biaya input tetap (fixed cost) per unit output menurun sehingga keuntungan produsen akan mengalami peningkatan. Namun demikian, teori Cobb-Douglas menyatakan bahwa perluasan skala usaha akan meningkatkan produksi hanya sampai pada batas tertentu. Selanjutnya perluasan skala usaha tidak berpengaruh terhadap hasil produksi, bahkan bisa menurunkan output produksi yang dihasilkan (Chavas, 2008).

Pola kerja petani bawang merah di Enrekang, termasuk di Kecamatan Baraka, masih menganut prinsip produksi model lama, dimana untuk menambah hasil panen harus dengan menambah input. Penambahan jumlah pupuk, bibit, dan tenaga kerja menjadi pilihan utama ketika para petani hendak meningkatkan produksi bawang merah mereka. Padahal jika dikaitkan dengan yang dinyakatan dalam teori Cobb-Douglas, penambahan input akan berkorelasi dengan 3 skenario. 
Gambar 1. Produksi dan Luas Panen di Baraka Tahun 2014-2018

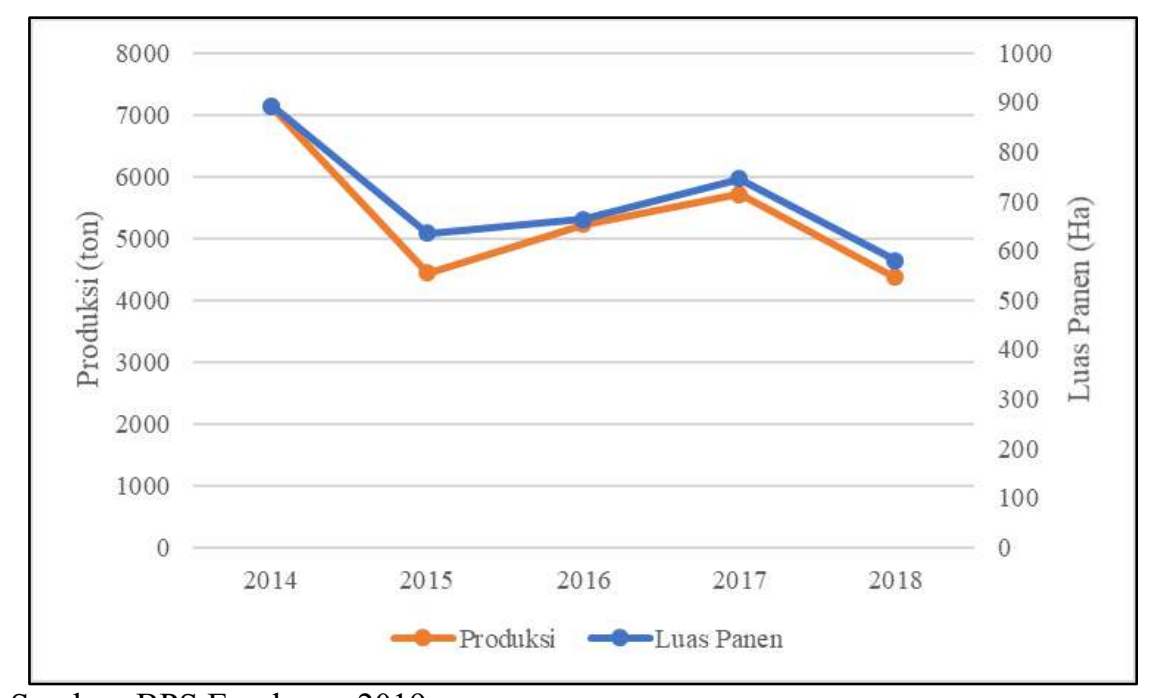

Sumber: BPS Enrekang, 2019

Jumlah produksi dan luas panen bawang merah di Baraka disajikan dalam Gambar 1. Berdasarkan pada ilustrasi tersebut terlihat bahwa pola kurva jumlah produksi bawang merah mengikuti pola kurva dari luas panen. Hal ini pada dasarnya sangat wajar, karena jumlah panen akan sejalan dengan luas lahan panen dari bawang merah itu. Namun demikian, dari ilustrasi ini terlihat bahwa pola penurunan (declaining) lebih besar daripada peningkatan (inclining) dari produksi bawang merah di Baraka. Dalam istilah teknis, dikatakan bahwa slope dari penurunan produksi lebih curam daripada penurunan produksi bawang merah.

Produksi bawang merah tentu ditentukan juga oleh input yang digunakan, diluar faktor lain seperti cuaca dan gejala alam lainnya. Dalam penelitian ini digunakan beberapa faktor input utama yang sering digunakan oleh petani bawang merah di Baraka, yaitu luas lahan, modal, tenaga kerja, dan teknologi.

Modal adalah salah satu faktor produksi yang digunakan dalam melakukan proses produksi. Dalam proses produksi tidak ada perbedaan antar modal sendiri atau pinjaman, yaitu masing-masing berperang langsung dalam proses produksi (Falo et al., 2016). Akumulasi modal terjadi apabila sebagian pendapatan dapat ditabung dan diinvestasikan kembali dengan tujuan memperbesar produktivitas dan pendapatan. Dilihat dari sisi modal, modal merupakan aspek yang harus di miliki oleh para petani bawang merah dengan modal yang terbatas maka kemampuan untuk membeli bibit benih dan teknologi terbatas. Disisi lain jumlah permintaan bawang merah yang semakin meningkat, produsen yang memiliki kemampuan memproduksi bawang merah juga terbatas. Hal ini membuat para petani bawang merah menerima pesanan dari konsumen dan melobi pembeli demi kelangsungan produksi dan supaya bawang merah juga laku dipasaran.

Untuk faktor produksi tenaga kerja masalah yang dihadapi oleh petani yaitu masih belom bisa mengalami regenerasi. Bisa dikatakan jumlah tenaga kerja semakin menurun. Tenaga kerja yang ada masih di dominasi oleh tenaga kerja yang usianya masih didominasi oleh usianya setengah baya atau lanjut usia. Karena kalangan muda enggan untuk bekerja pada sektor pertanian bawang merah tersebut. Selain itu, untuk memproduksi bawang merah juga membutuhkan tenaga kerja yang ahli dalam pertanian tersebut. Hal ini membuat produksi bawang merah menurun. Kalaupun produksi meningkat tapi harus ada penambahan lahan.

Teknologi merupakan salah satu faktor produksi yang digunakan dalam melakukan proses poduksi tanaman pertanian bawang merah. Penggunaan teknologi dalam pengelolahaan lahan pertanian bawang merah dapat mempermudah para petani dalam mengelolah lahan pertanian mereka. Selain itu penggunaan teknologi juga dapat membantu para petani dalam mengefisienkan waktu dan tenaga yang digunakan dalam mengelolah lahan pertanian. Salah satu penggunaan teknologi pada pertanian bawang merah adalah pengunaan mesin traktor. Pada awalnya proses pengolahan lahan bawang merah hanya mengunakan alat seperti linggis dan cangkul sehingga banyak menguras tenaga dan waktu yang digunakan dalam mengolah lahan relative lama, tetapi dengan masuknya teknologi dalam pengolahan lahan pertanian mempermudah petani dalam mengolah lahan pertanian mereka.

Secara teori, penggunaan input yang efektif akan menghasilkan produksi dengan hasil yang maksimal, dan tidak mubazzir dalam penggunaannya (Forijati, 2014; Kadir, 2016). Input yang efektif tidak berarti input yang banyak, namun lebih pada input yang seimbang dengan proses produksi yang dimiliki (Matson et al., 1997). 
Berdasarkan pada uraian tersebut, maka penelitian ini bertujuan untuk mengidentifikasi efektivitas penggunaan input pada usaha tani bawang merah di Kecamatan Baraka, Kabupaten Enrekang.

\section{Tinjauan Pustaka Teori Produksi}

Teori produksi yang sederhana menggambarkan tentang hubungan antara tingkat produksi suatu harga dengan jumlah tenaga kerja yang digunakan untuk menghasilkan berbagai tingkat produksi barang tersebut. Dalam analisis tersebut dimisalkan bahwa fakto-faktor produksi lainnya adalah tetap jumlahnya, yaitu modal dan jumlah tanah dianggap tidak mengalami perubahan. Juga teknologi dianggap tidak mengalami perubahan, satu-satunya faktor produksi yang dapat diubah jumlahnya adalah tenaga kerja.

Kegiatan produksi merupakan kegiatan dalam lingkup yang agak sempit karena banyak membahas aspek mikro. Dalam mempelajari aspek ini, peranan hubungan input (faktor produksi) dan output (hasil produksi) mendapatkan peranan utama. Peranan input bukan saja dapat dilihat dari segi macamnya atau tersedia dalam waktu yang tepat, tetapi dapat juga ditinjau dari segi efisiensi pwnggunaan faktor produksi seperti sumber daya, kelembagaan dan penunjang pembangunan pertanian. Karena faktor-faktor inilah maka terjadi adanya senjang produktifitas antara produktifitas yang seharusnya dan produktifitas yang dihasilkan oleh petani bawang merah. Dalam banyak kenyataan, produktifitas ini terjadi karna adanya faktor teknologi dan adanya perbedaan lingkungan, ,misalnya iklim. Untuk meningkatkan pemanfaatan sumber daya yang tersedia maka harus diperlukan adanya perubahan sumber daya melalui waktu, tempat dan bentuk dimanapun setiap perubahan yang meliputi perubahan faktor-faktor produksi sehingga dapat memperoleh hasil atau total produksi (output).

\section{Fungsi Cobb-Douglas \\ Metode Penelitian}

Penelitian ini merupakan penelitian kuantitatif dengan menggunakan analisis regresi berganda (multiple regression) sebagai alat analisis. Adapun lokasi penelitian berada di Kecamatan Baraka, Kabupaten Enrekang Provinsi Sulawesi Selatan pada tahun 2019.

Data yang digunakan adalah data primer yang diambil dari 34 orang petani sampel menggunakan metode simple random sampling. Data yang dibutuhkan dikumpulkan melalui obesrvasi langsung ke lokasi penelitian dan wawancara terbuka dengan menggunakan kuesioner.

Pengukuran efektivitas penggunaan input terhadap produksi dalam penelitian ini mengadopsi model produksi Cobb-Douglas. Model produksi ini adalah suatu model produksi atau persamaan yang menunjukkan pengaruh input yang digunakan dengna output yang diniginkan. Pendekatan Cobb-Douglas merupakan bentuk fungsional dari fungsi produksi secara luas yang digunakan untuk mewakili hubungan output untuk input (Amalia, 2014).

Untuk model produksi Cobb-Douglas itu sendiri dapat dituliskan sebagai berikut:

$$
\mathrm{Q}=\mathrm{A} \cdot \mathrm{K}^{\alpha} \mathrm{L}^{1-\alpha}
$$

Dengan variabel A adalah intersep, $\mathrm{K}$ adalah modal, dan $\mathrm{L}$ adalah tenaga kerja. Variabel $\alpha$ menunjukkan besarnya elastisitas output terhadap modal. Penjumlahan nilai $\alpha$ dan $\beta$ inilah yang kemudian menunjukkan pola return to scale atau homogenity degree-nya dengan skenario (Amalia, 2014):

- $\alpha+\beta>1$, increasing return to scale artinya terdapat tambahan hasil yang meningkat atas skala produksi.

- $\alpha+\beta<1$, decreasing return to scale artinya terdapat tambahan hasil yang menurun atas skala produksi.

- $\alpha+\beta=1$, constant return to scale artinya terdapat tambahan hasil yang konstan atas skala produksi.

Secara matematis, fungsi Cobb-Douglas pada persamaan (1) dapat diubah menjadi bentuk linear berganda melalui transformasi logaritma natural $(\ln )$ menjadi

$$
\ln Y=\ln A+\beta_{1} X_{1}+\beta_{2} X_{2}+\beta_{3} X_{3}+\beta_{3} X_{3}+\varepsilon
$$
produksi.

Dimana, $\mathrm{Y}$ adalah variabel output dan $\mathrm{X}$ adalah variabel input yang digunakan dalam proses

Penelitian ini menggunakan produksi bawang merah sebagai variabel output, dengan luas lahan, modal, tenaga kerja, dan teknologi sebagai variabel inputnya.

Dengan memasukkan masing-masing variabel penelitian ke dalam persamaan (2), maka model persamaan dalam penelitian ini adalah sebagai berikut: 
Keterangan:

$$
\begin{array}{ll}
\text { Prod } & =\text { Produksi } \\
\text { Lhn } & =\text { Luas Lahan } \\
\text { Mdl } & =\text { Modal } \\
\text { TK } & =\text { Tenaga Kerja } \\
\text { Tk } & =\text { Teknologi } \\
\varepsilon & =\text { Kesalahan pengganggu }
\end{array}
$$

Model regresi berganda mewajibkan dilakukannya pengujian terhadap asumsi klasik yang meliputi uji normalitas, uji multikolinearitas, uji autokorelasi, dan uji heteroskedastisitas. Sedangkan untuk pengujian hipotesisnya menggunakan uji koefisien determinasi $\left(\mathrm{R}^{2}\right)$, uji F, dan uji t (Gujarati, 2004).

\section{Hasil dan Pembahasan}

\section{Uji Asumsi Klasik}

Langkah pertama dalam penggunaan model regresi linear berganda sebagai alat analisis adalah melakukan pengujian terhadap asumsi klasik.

\section{Uji Normalitas}

Pengujian terhadap normalitas data bertujuan untuk melihat apakah residual data yang digunakan dalam model regresi terdistribusi secara normal atau tidak (Nuryanto \& Pambuko, 2018). Pada penelitian ini pengujian normalitas data menggunakan uji Kolgomorov-Smirnov. Kriteria yang digunakan adalah dengan membandingkan nilai dari probabilitas dari Kolgomorov-Smirnov dengan $\alpha(0,05)$. Jika nilai probabilitas Kolgomorov-Smirnov lebih besar $(>)$ daripada $\alpha(0,05)$ maka data dikatakan terdistribusi secara normal. Sebaliknya, jika nilai probabilitasnya lebih kecil $(<)$ daripada $\alpha(0,05)$ maka data tidak terdistribusi secara normal (Pramesti, 2016).

Tabel 2. Hasil Uji Normalitas

\begin{tabular}{ccc}
\hline $\begin{array}{c}\text { Kolgomorov- } \\
\text { Smirnov }\end{array}$ & Prob. & Kesimpulan \\
\hline 0,725 & 0,670 & Normal \\
\hline
\end{tabular}

Sumber: Data diolah, 2019

Pada tabel 2 tersebut diketahui bahwa nilai probabilitasnya sebesar 0,670> $>(0,05)$. Artinya adalah model yang digunakan mempunyai residual atau faktor pengganggu yang terdistribusi secara normal.

\section{Uji Multikolinearitas}

Pengujian asumsi klasik selanjutnya adalah uji multikolinearitas. Uji ini bertujuan untuk menguji apakah dalam model regresi ditemukan korelasi antar variabel independen. Pengujiannya menggunakan indikator nilai variance inflation factor (VIF) dan tolerance. Kriterianya adalah jika nilai VIF model penelitian $<10$ maka disimpulkan bahwa tidak terjadi multikolinearitas. Sebaliknya, jika nilai VIF model $>$ 10 maka dinyatakan terjadi gejala multikolinearitas (Pramesti, 2016).

Tabel 3. Hasil Uji Multikolinearitas

\begin{tabular}{ccc}
\hline Variabel & VIF & Kesimpulan \\
\hline Luas Lahan & 2,548 & Bebas \\
\hline Modal & 1,522 & Bebas \\
\hline Tenaga Kerja & 1,119 & Bebas \\
\hline Teknologi & 2,993 & Bebas
\end{tabular}

Sumber: Data diolah, 2019

Berdasarkan pada hasil pengujian multikolinearitas seperti yang disajikan dalam Tabel 3 di atas, maka disimpulkan bahwa semua variabel independen bebas dari gejala multikolinearitas. 


\section{Uji Autokorelasi}

Pengujian autokorelasi bertujuan untuk menguji apakah pada model regresi terdapat korelasi antara kesalahan pengganggu pada periode $t\left(\varepsilon_{t}\right)$ dengan kesalahan pada periode sebelumnya $\left(\varepsilon_{t-1}\right)$. Pengujian ada tidaknya autokorelasi menggunakan uji Durbin-Watson (D-W test). Kriteriaya adalah dengan membandingkan antara nilai D-W hitung yang diperoleh dari hasil regresi persamaan struktural (3) dengan nilai D-W tabel yang menghasilkan nilai $d L$ dan $d U$ (Chatfield, 2014).

Hasil regresi persamaan struktural (3) mendapatkan nilai D-W hitung sebesar 2,169. Adapun nilai $d L$ dan $d U$ yang didapatkan dari tabel D-W adalah 1,2078 dan 1,7277.

\section{Gambar 2. Uji Autokorelasi}

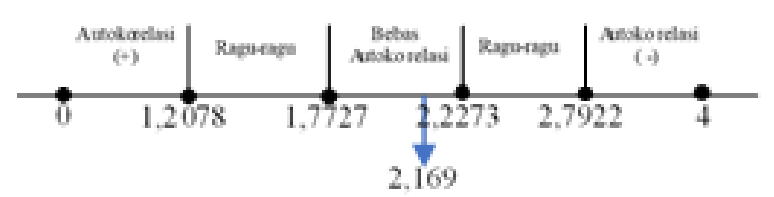

Berdasarkan pada Gambar 3 yang merupakan ilustrasi terhadap hasil pengujian autokorelasi menggunakan Durbin-Watson, ditemukan bahwa nilai D-W hitung berada di area bebas autokorelasi $\left(d U<\mathrm{DW}_{\text {hitung }}<4\right.$ $d U)$.

\section{Uji Heteroskedastisitas}

Pengujian asumsi klasik yang terakhir adalah uji heteroskedastisitas. Pengujian ini bertujuan untuk menguji apakah dalam model regresi terjadi ketidaksamaan varians dari residual satu pengamatan ke pengamatan yang lain (Amalia, 2014). Untuk mengetahui ada tidaknya gejala heteroskedastisitas dilakukan melalui uji Breusch-Pagan-Godfrey. Kriteria yang digunakan dalam pengambilan keputusan adalah dengan melihat nilai dari probabilitasnya. Gejala hetoroskedastisitas terjadi ketika nilai probabilitasnya lebih kecil $(<)$ daripada $\alpha(0,05)$, sebaliknya jika lebih besar $(>)$ dari $\alpha(0,05)$ maka tidak terjadi heteroskedastisitas.

Tabel 4. Hasil Uji Heteroskedastisitas

\begin{tabular}{ccc}
\hline Nilai & Prob. & Kesimpulan \\
\hline $\mathbf{1 , 8 6 9 3 0 7}$ & 0,6000 & Tidak ada \\
\hline
\end{tabular}

Sumber: Data diolah, 2019

Berdasarkan pada hasil pengujian menggunakan uji Breusch-Pagan-Godfrey diperoleh nilai probabilitas $0,600<\alpha(0,05)$. Dengan demikian maka model regresi bebas dari gejala heteroskedastisitas.

\section{Uji Hipotesis}

Pengujian hipotesis dalam penelitian ini menggunakan model regresi linear berganda yang bertujuan untuk melihat pengaruh variabel-variabel independen (bebas) terhadap variabel dependen (terikat).

Pengujian hipotesis menggunakan 3 standar pengujian yaitu, koefisien determinan $\left(\mathrm{R}^{2}\right)$, uji $\mathrm{F}$, dan uji t.

\section{Koefisien Determinasi}

Uji koefisien determinasi $\left(\mathrm{R}^{2}\right)$ pada dasarnya bertujuan untuk mengukur seberapa besar kemampuan variabel-variabel bebas dalam menerangkan variabel terikatnya (Nuryanto \& Pambuko, 2018).

\begin{tabular}{ccc}
\multicolumn{3}{c}{ Tabel 5. Koefisien Determinasi } \\
\hline $\mathbf{R}$ & R-square & Adj. R-Square \\
\hline 0,550 & 0,303 & 0,206 \\
\hline
\end{tabular}

Sumber: Data diolah, 2019

Berdasarkan pada hasil regresi persamaan struktural (3) diperoleh nilai koefisien determinasi sebesar 0,303 . Artinya bahwa variasi nilai variabel independen mampu menjelaskan variasi nilai variabel dependen sebesar 30,3\%, sisanya yaitu 69,7\% dijelaskan oleh variabel lain di luar model yang diregresikan. 


\section{Uji F}

Dalam konteks pelaksanaan uji $\mathrm{F}$ dalam penelitian ini, dimaksudkan untuk melihat apakah variabel luas lahan, modal, tenaga kerja, dan teknologi secara serentak berpengaruh terhadap produksi atau tidak.

Hasil regresi pada persamaan struktural menunjukkan bahwa nilai probabilitas dari $\mathrm{F}_{\text {hitung }}$ adalah sebesar 0,029. Nilai ini lebih kecil daripadan $\alpha(0,05)$, sehingga dapat dikatakan bahwa variabel independen secara simultan berpengaruh signifikan terhadap tingkat produksi bawang merah di Baraka Kabupaten Enrekang.

\section{Uji t}

Uji statistik menggunakan uji t bertujuan untuk melihat seberapa jauh satu variabel independen secara individual berpengaruh terhadap variabel dependen (Amalia, 2014). Pelaksanaan uji t dilakukan dengan cara melihat nilai probabilitas dari t hitung masing-masing variabel independen terhadap variabel dependen. Jika nilai probabilitas dari t hitung variabel tersebut lebih kecil dari nilai $\alpha(0,05)$ maka variabel tersebut dikatakan berpengaruh signifikan terhadap variabel dependen.

\begin{tabular}{lccc}
\multicolumn{4}{c}{ Tabel 6. Hasil Uji t } \\
\hline Variabel & t hitung & Sig. & Koef. \\
\hline Constant & 1,482 & 0,149 & 7,452 \\
\hline LnLhn & 2,562 & 0,029 & 0,561 \\
\hline LnMdl & 1,710 & 0,003 & 0,249 \\
\hline LnTK & 2,687 & 0,048 & 0,033 \\
\hline LnTk & 0,937 & 0,357 & 0,485
\end{tabular}

Sumber: Data diolah, 2019

Tabel 6 menyajikan hasil uji t variabel independen terhadap variabel dependen.

\section{Pengaruh Luas Lahan terhadap Produksi}

Dari pengolahan data berupa uji t, diperoleh hasil bahwa variabel luas lahan memiliki nilai signifikasi $0,029<0,05$ dengan besar koefisien 0,561. Hal ini berarti variabel luas lahan berpengaruh signifikan terhadap produksi bawang merah dengan tingkat kepercayaan 95\% dan besar pengaruh 0,561.

\section{Pengaruh Modal terhadap Produksi}

Dari pengolahan data berupa uji t, diperoleh hasil bahwa variabel modal memiliki nilai signifikasi $0,003<0,05$ dengan besar koefisien 0,249 . Hal ini berarti variabel modal berpengaruh signifikan terhadap produksi bawang merah dengan tingkat kepercayaan 95\% dan besar pengaruh 0,249.

\section{Pengaruh Tenaga Kerja terhadap Produksi}

Dari pengolahan data berupa uji t, diperoleh hasil bahwa variabel teanga kerja memiliki nilai signifikasi $0,048<0,05$ dengan besar koefisien 0,033 . Hal ini berarti variabel tenaga kerja berpengaruh signifikan terhadap produksi bawang merah dengan tingkat kepercayaan 95\% dan besar pengaruh 0,033 .

\section{Pengaruh Teknologi terhadap Produksi}

Dari pengolahan data berupa uji t, diperoleh hasil bahwa variabel teknologi memiliki nilai signifikasi 0,357>0,05 dengan besar koefisien 0,249. Hal ini berarti variabel teknologi tidak berpengaruh signifikan terhadap produksi bawang merah pada tingkat kepercayaan $95 \%$.

\section{Analisis Fungsi Cobb-Douglas}

Berdasarkan pada hasil pengujian hipotesis di atas, maka diperoleh model fungsi Cobb-Douglas sebagai berikut:

$\ln$ Prod $=1,482+0,56 \mathrm{Lhn}+0,249 \mathrm{Mdl}+0,033 \mathrm{TK}+0,485 \mathrm{Tk}+\varepsilon$

Hasil persamaan Cobb-Douglas tersebut dapat diinterpretasikan sebagai berikut:

- Apabila seluruh variabel independen tidak mengalami perubahan (konstan) maka output bawang merah akan meningkat sebesar 1,482. 
- Nilai koefisien regresi untuk variabel luas lahan (Lhn) adalah sebesar 0,561. Artinya jika luas lahan mengalami peningkatan sebesar 1 persen, dan variabel lain dianggap konstan (ceteris paribus) maka produksi bawang merah akan meningkat sebesar 0,561 persen.

- Nilai koefisien regresi untuk variabel modal (Mdl) adalah sebesar 0,249. Artinya jika modal mengalami peningkatan sebesar 1 persen, dan variabel lain dianggap konstan (ceteris paribus) maka produksi bawang merah akan meningkat sebesar 0,249 persen.

- Nilai koefisien regresi untuk variabel teanga kerja (TK) adalah sebesar 0,033. Artinya jika tenaga kerja mengalami peningkatan sebesar 1 persen, dan variabel lain dianggap konstan (ceteris paribus) maka produksi bawang merah akan meningkat sebesar 0,033 persen.

- Nilai koefisien regresi untuk variabel teknologi (Tk) adalah sebesar 0,485 tetapi tidak signifikan secara statistik. Artinya teknologi tidak mempengaruhi produksi bawang merah di Baraka Kabupaten Enrekang.

Untuk dapat mengetahui pengaruh penggunaan input terhadap output, elastisitas masing-masing faktor input dan skala usaha dilakukan analisis sebagai berikut (Amalia, 2014).

\begin{tabular}{lll} 
& Tabel 7. Elastisitas Input \\
\hline Variabel & Koef. & Sifat \\
\hline LnLhn & 0,561 & Inelastis \\
\hline LnMdl & 0,249 & Inelastis \\
\hline LnTK & 0,033 & Inelastis \\
\hline LnTk & 0,485 & Inelastis \\
\hline
\end{tabular}

Sumber: Data diolah, 2019

Hasil analisis terhadap elastisitas input ditemukan bahwa seluruh variabel bersifat inelastis terhadap produksi bawang merah yang dibudidayakan di Baraka Kabupaten Enrekang. Kondisi ini berarti bahwa setiap penambahan faktor input hanya akan menghasilkan penambahan produksi yang lebih rendah. Secara statistik, untuk menambah atau meningkatkan jumlah produksi bawang merah yang dibudidayakan oleh petani di Baraka, maka mereka penambahan lahan, modal, tenaga kerja, dan teknologi tidak terlalu diperlukan.

Berdasarkan pada hasil estimasi, maka dapat dihitung besarnya homogenity degree dari fungsi produksi bawang merah diteliti. Homogenity degree diperoleh dari penjumlahan nilai koefisien masingmasing variabel $(0,561+0,249+0,033+0,485)$ sehingga diperoleh hasil sebesar 1,328 atau lebih besar dari 1 .

Nilai homogenity degree yang lebih dari 1 berarti bahwa fungsi produksi bawang merah di Baraka Kabupaten Enrekang berada pada kondisi increasing return scale. Artinya persentase peningkatan output lebih besar dari persentase peningkatan input. Secara empiris, hasil ini dapat dikatakan bahwa jika petani melakukan penambahan input (luas lahan, modal, tenaga kerja, dan teknologi) secara serentak, maka akan berdampak pada peningkatan produksi bawang merah. Hal ini juga mengindikasikan bahwa masih ada celah yang bisa dimanfaatkan oleh petani bawang merah untuk menambah produksi mereka melalui penambahan input secara serentak.

\section{KESIMPULAN}

Berdasarkan pada hasil analisis dan pembahasan yang telah dilakukan maka dapat dibuat beberapa kesimpulan. Pertama, secara bersama-sama luas lahan, modal, tenaga kerja dan teknologi berpengaruh signifikan terhadap produksi merah di Baraka Kabupaten Enrekang.

Kedua, secara individual variabel luas lahan, modal, dan tenaga kerja berpengaruh signfikan terhadap produksi bawang merah. Sedangkan variabel teknologi tidak berpengaruh terhadap produksi bawang merah.

Ketiga, semua variabel input yang digunakan penelitian ini secara individual memiliki sifat inelastis terhadap produksi bawang merah. Artinya penambahan input secara individual tidak efektif dapat meningkatkan produksi bawang merah.

Keempat, perhitungan homogenity degree yang merujuk pada efisiensi penggunaan input pada produksi bawang merah di Baraka Kabupaten Enrekang berada pada kondisi increasing return to scale. 


\section{DAFTAR PUSTAKA}

Aldila, H. F., Fariyanti, A., \& Tinaprilla, N. (2017). Daya Saing Bawang Merah di Wilayah Sentra Produksi di Indonesia. Jurnal Manajemen dan Agribisnis. https://doi.org/10.17358/jma.14.1.43

Amalia, F. (2014). Analisis Fungsi Produksi Cobb-Douglas Pada Kegiatan Sektor Usaha Mikro di Lingkungan UIN Syarif Hidayatullah Jakarta. Signifikan: Jurnal Ilmu Ekonomi. https://doi.org/10.15408/sigf.v3i1.2056

Chatfield, C. (2014). Durbin-Watson Test. In Wiley StatsRef: Statistics Reference Online. https://doi.org/10.1002/9781118445112.stat05503

Chavas, J. P. (2008). On the Economics of Agricultural Production. Australian Journal of Agricultural and Resource Economics. https://doi.org/10.1111/j.1467-8489.2008.00442.x

Cobb, C., \& Douglas, P. (1928). A Theory of Production. In American Economic Association. https://doi.org/10.1515/humr.1998.11.2.161

Djauhari, A., \& Malian, A. H. (2016). Pemasaran Cabai dan Bawang Merah (Sebuah Studi di Daerah Sistem Sorjan). Forum Penelitian Agro Ekonomi. https://doi.org/10.21082/fae.v1n1.1982.55-64

Falo, M., Kune, S. J., Hutapea, A. N., \& Kapitan, O. B. (2016). Faktor-Faktor yang Mempengaruhi Produksi dan Strategi Pengembangan Usahatani Bawang Putih di Kecamatan Miomaffo Barat, Kabupaten Timor Tengah Utara. AGRIMOR. https://doi.org/10.32938/ag.v1i04.113

Forijati. (2014). Pengaruh Skala Ekonomi Terhadap Produktivitas dan Efisiensi dalam Ekonomi Islam. Konferensi Internasional Pembangunan Islami - I.

Gujarati, D. N. (2004). Basic Econometrics 4th Edition. In Tata McGraw-Hill. https://doi.org/10.1126/science. 1186874

Kadir, A. (2016). Konsep Produksi Dalam Perspektif Ekonomi Syariah. EcceS (Economics, Social, and Development Studies).

Matson, P. A., Parton, W. J., Power, A. G., \& Swift, M. J. (1997). Agricultural Intensification and Ecosystem Properties. Science. https://doi.org/10.1126/science.277.5325.504

McAuliffe, R. E. (2015). Cobb-Douglas Production Function. In Wiley Encyclopedia of Management. https://doi.org/10.1002/9781118785317.weom080116

Muhammad Idrus. (2013). Analisis Pendapatan Usaha Tani Bawang Merah di Kelurahan Mataran Kecamatan Anggeraja Kabupaten Enrekang. Jurnal Economix. https://doi.org/10.1002/jcop.21624

Nuryanto, \& Pambuko, Z. (2018). Eviews Untuk Analisis Ekonometrika Dasar: Aplikasi dan Interpretasi. In UNIMMA PRESS. https://doi.org/10.1017/CBO9781107415324.004

Pramesti, G. (2016). Statistika Lengkap Secara Teori dan Aplikasi dengan SPSS 23. In Elex Media Komputindo.

Shephard, R. W. (2015). Theory of Cost and Production Functions. In Theory of Cost and Production Functions. https://doi.org/10.2307/2230285

Soekartawi. (2002). Analisis Usahatani. In Universitas Indonesia Press. 